\section{Treament and prevention of anemia with ferrous sulfate plus folic acid in children attending daycare centers in Goiânia, Goiás State, Brazil: a randomized controlled trial}

\author{
Resposta terapêutica e profilática com ferro e \\ ácido fólico na anemia em crianças de creches \\ públicas em Goiânia, Goiás, Brasil: ensaio clínico \\ randomizado
}

\author{
Maria Claret Costa Monteiro Hadler 1 \\ Dirce Maria Sigulem 2 \\ Maria de Fátima Costa Alves 3 \\ Vinícius Montenegro Torres 4
}

\footnotetext{
1 Faculdade de Nutrição, Universidade Federal de Goiás, Goiânia, Brasil. 2 Universidade Federal de São Paulo, São Paulo, Brasil. 3 Instituto de Patologia Tropical e Saúde Pública, Universidade Federal de Goiás, Goiânia, Brasil 4 Vila São José Bento Cotolengo, Trindade, Brasil.

Correspondence M. C. C. M. Hadler Faculdade de Nutrição, Universidade Federal de Goiás.

Av. T-4 802, apto. 802 Setor Bueno, Goiânia, GO 74230-030, Brasil. clarethadler@uol.com.br
}

\begin{abstract}
The objective of this study was to assess the prevalence of anemia and the therapeutic and prophylactic response to ferrous sulfate and folic acid. A double-blind, randomized, controlled clinical trial was conducted with 196 children 6 to 24 months of age enrolled in municipal daycare centers in Goiânia, Goiás State, Brazil. The children were assigned to two treatment groups that received a daily dose (5 times a week) of either $4.2 \mathrm{mg} / \mathrm{kg} /$ day of ferrous sulfate + folic acid $(50 \mu \mathrm{g})$ or $4.2 \mathrm{mg} / \mathrm{kg} /$ day of ferrous sulfate + folic acid placebo. One of the prevention groups received $1.4 \mathrm{mg} / \mathrm{kg} /$ day of ferrous sulfate + folic acid (50 $\mathrm{g} / \mathrm{day})$ and the other $1.4 \mathrm{mg} / \mathrm{kg} /$ day of ferrous sulfate + folic acid placebo. Supplementation lasted approximately three months. Baseline anemia prevalence was 56.1\% (95\%CI: 48.963.1). After treatment, anemia prevalence in the folic acid group (14\%) was lower than in the placebo group (34.9\%) ( $p=0.02)$. After prophylaxis in the non-anemic children, the incidence of anemia did not differ between the groups, but there was an increase in hemoglobin level in the folic acid group ( $p=0.003)$. Iron plus folic acid was effective for the treatment of anemia and improvement of hemoglobin level in non-anemic children.
\end{abstract}

Nutritional Epidemiology; Anemia; Ferrous Sulfate; Folic Acid; Child Day Care Centers

\section{Introduction}

Nutritional anemia can be due to iron, folic acid, or vitamin B12 deficiency 1 . Iron is the main nutrient involved in nutritional anemia, followed by folic acid 2 . Deoxyribonucleic acid (DNA) synthesis depends on the coenzyme folate for the biosynthesis of the nucleotide pyrimidine, which is required for cell division ${ }^{3}$, and folate is thus one of the necessary nutrients for hematopoiesis 4 .

Iron deficiency anemia is the most common nutritional problem in the world 5, with a negative impact on mental, motor, cognitive, and immune development $6,7,8$. An anemia prevalence greater than or equal to $40 \%$ is considered a serious public health problem ${ }^{4}$, and in Brazil children 6 to 24 months of age constitute one of the most vulnerable groups 9,10 .

The World Health Organization and the Brazilian Ministry of Health recommend that infants receive exclusive breastfeeding until six months of life 11. It has been shown that absorption of iron from breast milk is reduced by the consumption of other foods or beverages, particularly before or after breatfeeding ${ }^{12}$. With the introduction of supplementary feeding, infants require an additional source of iron to prevent iron deficiency anemia 4 . Various studies have used various intermittent doses at different weekly frequencies for anemia prevention and treatment 13,14,15,16. Although the use of iron supplements is recommended for infants in areas with high prevalence 
of anemia, their efficacy has not been totally elucidated 17

Some studies have suggested that other factors besides iron can limit the hemoglobin response and control of anemia, like vitamin A and other micronutrients or non-nutritional factors 13. A study of Mexican children showed that iron, vitamin A, vitamin B12, vitamin E, and riboflavin deficiencies were common at baseline. The authors observed that many children receiving iron supplements remained anemic (30\%) after six months of treatment and at 12 months (31\%), despite the eradication of iron deficiency 18 . Thus, supplementation with one or more nutrients is one of the strategies to fight borderline micronutrient deficiency, since it can increase the effectiveness of programs to fight anemia. However, there is still limited information on interactions between micronutrients (when supplemented), based on pharmacological studies ${ }^{19}$. It is important to assess the efficacy and effectiveness of iron supplementation compared to the combination of iron and folic acid in children younger than 24 months 20 . In addition, the possibility of meeting the multiple needs for these micronutrients makes this an interesting strategy 21.

The objectives of this study were to evaluate the prevalence of anemia in children from 6 to 24 months of age and the therapeutic and prophylactic response to ferrous sulfate plus folic acid on hemoglobin levels, in municipal daycare centers in Goiânia, Goiás State, Brazil.

\section{Methods}

\section{Sampling}

In 2005, Goiânia had 67 municipal preschools, of which 53 included daycare centers with 447 children from 6 to 24 months of age. These are fulltime preschools where children participate in educational activities with teachers trained in pedagogy or teaching, along with preschool staff. The centers are operated by the Goiânia Municipal Department of Education.

Children were selected through probabilistic sampling, i.e., the number of children from 6 to 24 months of age was checked at the municipal preschools that had daycare centers, and the probability of the daycare center being picked was proportional to the number of children enrolled there. Twenty-five daycare centers were selected, with 268 children, using a probabilistic draw and the Excel random numbers table (Microsoft Corp., USA). After application of the exclusion criteria and one refusal, 219 children were finally selected.
- Population: universe of children from 6 to 24 months of age attending municipal preschools with daycare in the year 2005.

- Sample: included 219 children from 6 to 24 months of age, born at term, non-twins, with parental approval for participation in the study, and who were attending municipal daycare centers with more than four children each. Exclusion criteria were: children with special needs, low birth weight $(<2,500 \mathrm{~g})$, with growth-impairing heart diseases or neurological syndromes, with sicklecell anemia or sickle-cell trait, under treatment for anemia at the time of the first interview or screening performed by the pediatrician, and those no longer attending the daycare center. The clinical trial excluded children with hemoglobin $\geq 7$ and $<8 \mathrm{~g} / \mathrm{dL}$, adopting the cutoff for exclusion used by Tee et al. 22 .

To design the intervention with 40 children in each treatment arm, with the aim of detecting a minimum difference of $0.5 \mathrm{~g} / \mathrm{dL}$ with a standard deviation of 0.7 and significance of 0.05 , the test power was 0.89 . This sample size is sufficient to detect differences of the same magnitude between the groups. The SAMPSI procedure from Stata 7.0 (Stata Corp., College Station, USA) was used for calculation.

A safety margin of $24 \%$ was added to the initially predicted sample of 160 children to cover potential losses during the study. Of the 219 selected children, eight left the daycare center, four failed to appear for blood samples, and the parents of eight canceled the original informed consent. Thus, 199 children participated in the first blood draw. Of these, three did not perform the complete blood count, so the assessment of anemia prevalence used a sample of 196 children that participated in the subdivision of groups for the clinical trial (Figure 1). Since four children presented hemoglobin $\geq 7$ and $<8.0 \mathrm{~g} / \mathrm{dL}$, they were submitted to special treatment prescribed by the pediatrician and were therefore excluded. Thus, from the initial sample to the randomization for the clinical trial, a sample of 192 children was established, but eight of them left the daycare centers before beginning medication. Therefore, 184 children actually began treatment with ferrous sulfate, and 161 of them $(87.5 \%)$ concluded the treatment (Figure 1). Thus, there was a loss of $12.5 \%$ among the children that began treatment, and a total sample loss of $19.1 \%(161 / 199)$ among those that appeared for the first blood sample until the end of the experiment.

\section{Study design}

The current studywas part of a larger project called Nutritional Anemia: Prevention and Treatment in 


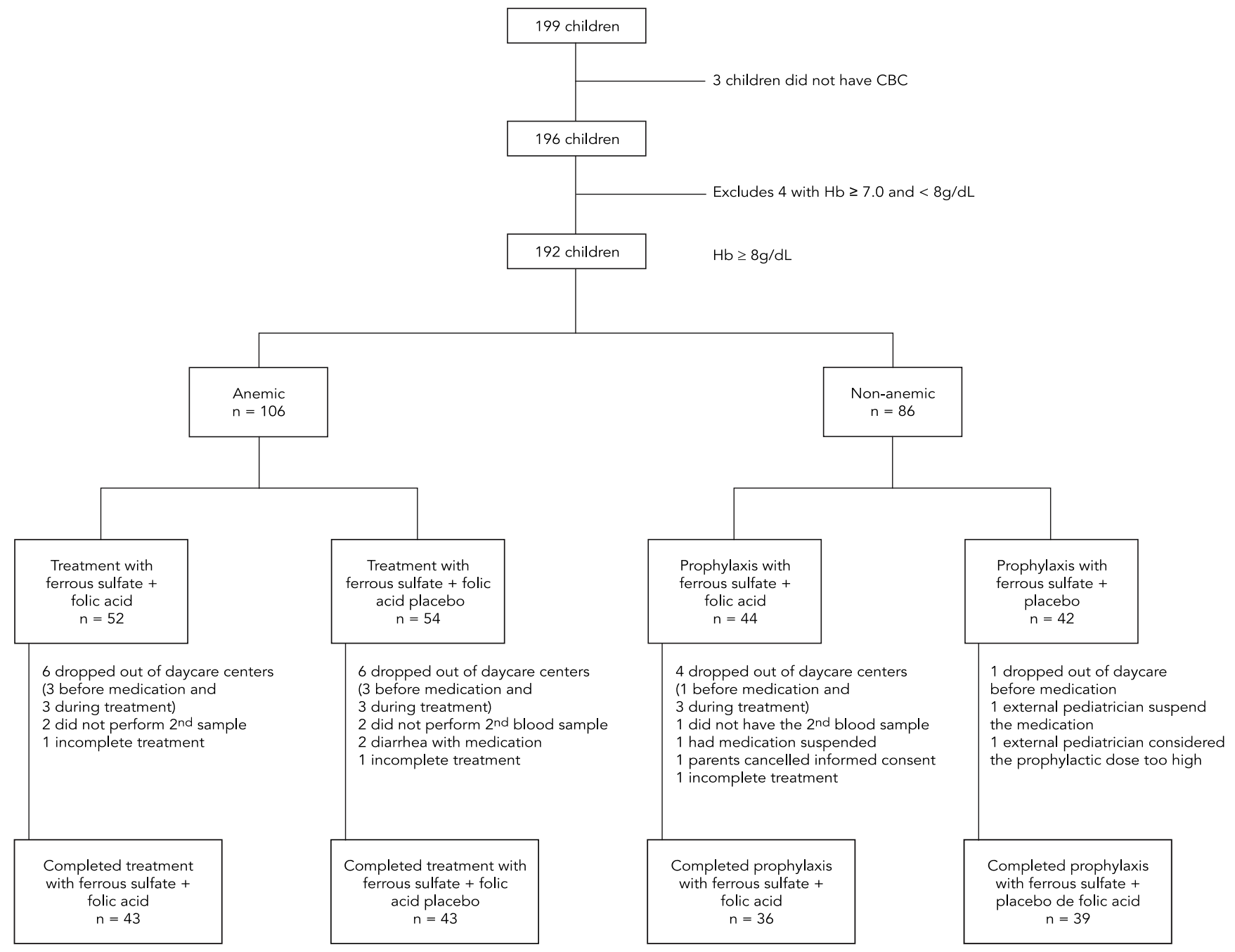

CBC: complete blood count.

Early Childhood, which aimed to assess the causality of anemia and diet and to compare different micronutrient supplements in the prevention and treatment of anemia in early childhood. The study done in Goiânia from April 2005 to March 2006 was therapeutic, according to the Medical Research Council (MRC), since it involved both treatment and prevention of diseases 23 .

This was a controlled, randomized, prospective, double-blind clinical trial with 192 children from 6 to 24 months of age. The design was lon- gitudinal, and the research unit was children in this age bracket on the date the first blood sample was drawn.

After informing the children's parents/guardians and obtaining written informed consent in duplicate, the first interview was held for sample selection and screening by the pediatrician to determine whether the child was eligible to participate in the study.

The study collected socioeconomic and cultural data and information on the parents; re- 
alizes food and anthropometric surveys, blood counts and blood chemistry, stool tests, and fecal occult blood. Clinical examination of the participating children, using a previously tested form with modifications 14 and clinical charts. The interviewers were students, interns, and scientific initiation or extension scholarship students from the undergraduate course in nutrition, as well as a nutritionist and faculty members from the School of Nutrition, Federal University in Goiás (UFG), all previously trained.

Parents were informed that the blood tests posed no risk of contamination or infection, and that they could cancel their consent at any time, without harm the care provided to their children.

\section{Intervention}

For the intervention, the daycare centers were divided into four groups. Groups A and C received ferrous sulfate at different concentrations plus folic acid placebo for the prevention and treatment of anemia, and Groups B and D received ferrous sulfate plus folic acid.

- Group A: daily treatment with $4.2 \mathrm{mg} / \mathrm{kg} /$ day of ferrous sulfate + folic acid placebo.

- Group B: daily treatment with $4.2 \mathrm{mg} / \mathrm{kg} /$ day of ferrous sulfate + folic acid (50 $\mu$ g/day).

- Group C: daily prophylaxis with $1.4 \mathrm{mg} / \mathrm{kg} /$ day of ferrous sulfate + folic acid placebo.

- Group D: daily prophylaxis with $1.4 \mathrm{mg} / \mathrm{kg} /$ day of ferrous sulfate + folic acid $(50 \mu \mathrm{g} /$ day $)$.

Ferrous sulfate drops were used with $25 \mathrm{mg}$ of elemental iron per $\mathrm{mL}$. The dose administered to each child was calculated and prescribed by the pediatrician responsible for the children's follow-up, prevention, and treatment, based on the child's body weight as measured on the day of the first blood sample. Anemic children were treated with $4.2 \mathrm{mg} / \mathrm{kg} /$ day of ferrous sulfate, with or without folic acid, administered five days a week (Monday to Friday), the equivalent of a mean daily treatment dose of $3 \mathrm{mg} / \mathrm{kg} /$ day ${ }^{4}$. Non-anemic children $(\mathrm{Hb} \geq 1 \mathrm{~g} / \mathrm{dL})$ received $1.4 \mathrm{mg} / \mathrm{kg} /$ day of ferrous sulfate five days a week, corresponding to a daily dose of $1 \mathrm{mg} / \mathrm{kg} /$ day. This is the dose recommended by the Brazilian Society of Pediatrics since 1995, beginning with the introduction of food supplementation at 24 months of age 24 , and by the American Academy of Pediatrics for term infants with birth weight $>2,500 \mathrm{~g} 25$.

Folic acid supplementation of $50 \mu \mathrm{g} /$ day was based on Stoltzfus \& Dreyfuss 20.

The pediatrician provided one copy of the test results to the mothers. The number of drops to be administered was written on a medical prescription that was kept in the daycare center, and these amounts were also recorded on the medication sheet.

The teachers, school staff, and nutrition interns were trained to administer the medication and record the data on the forms. The interns also acted as supervisors, and every two to three days, besides administering the medication (ferrous sulfate and then folic acid drops), they checked the forms to see whether the teachers or school staff had properly administered and recorded the medication on the other days of the week. On the days without supervision, the control was also done by means of telephone calls.

The children in each group of daycare centers received a median of 67 doses of medication. At the end of treatment, they had new blood counts and blood chemistry tests. Children that presented anemia and/or iron deficiency at the second examination received ferrous sulfate for two more months, furnished free of cost. Parents were instructed to bring their children to the nearest health clinic for a follow-up examination.

\section{Blinding and use of placebo}

Blinding was applied to the folic acid. In this study the mothers (who were informed ahead of time) and the other participants did not know whether folic acid or folic acid placebo was being administered. The variable with the type of medication administered was only included after duplicate keying-in of the data and performing VALIDATE in Epi Info 6.04d (Centers for Disease Control and Prevention, Atlanta, USA).

The placebo and folic acid were manufactured by a pharmaceutical company according to the required standards, using identical bottles and packaging, distinguished only by the batch number, with no potential conflict of interests. A control card was used to deliver the medicines to the daycare centers, to avoid possible switching of batches.

\section{Blood counts and blood biochemistry}

At baseline and at the end of treatment, aliquots of 8 to $10 \mathrm{~mL}$ of fasting venous blood were drawn with disposable syringes and needles, placed in three separate tubes for: (1) a complete blood count (CBC); (2) folic acid and vitamin B12 analysis, with the tube wrapped in aluminum foil; and (3) ferritin and C-reactive protein, the latter capable of increasing ferritin in the presence of infection 4,26 .

CBC was performed with electronic counting in Cell-Dyn 3200 SL (Abbott Diagnostics, Mount View, USA), obtaining hemoglobin levels. Children with hemoglobin $<11 \mathrm{~g} / \mathrm{dL}$ were considered 
anemic ${ }^{4}$. Severity of anemia was classified as: severe when $\mathrm{Hb}<7.0 \mathrm{~g} / \mathrm{dL}$; moderate with $\mathrm{Hb} \geq$ 7.0 and $<9.0 \mathrm{~g} / \mathrm{dL}$; and mild with $\mathrm{Hb} \geq 9.0$ and $<$ $11 \mathrm{~g} / \mathrm{dL} 27$.

Serum ferritin was assessed by chemoluminescence in the AxSym system by Abbott Laboratories of Brazil Ltd., using the specific kit.

Serum C-reactive protein (CRP) was measured by turbidimetry in Konelab 60i (Wiener, Finland) at the Clinical Laboratory of the University Hospital of the Federal University in Goiás. Children with CRP $<0.50$ were considered inflammation-free.

Serum folate and vitamin B12 were measured by chemoluminescence with the Bayer Advia Centaur System (Bayer Diagnostics, Tarrytown, USA) at the Hermes Pardini Institute in Belo Horizonte. The cutoff points for detecting folic acid deficiency were $<3.0 \mathrm{ng} / \mathrm{mL}$ for high risk of deficiency, $3-5 \mathrm{ng} / \mathrm{mL}$ for moderate risk, and $>$ $5 \mathrm{ng} / \mathrm{mL}$ for low risk 28; vitamin B12 levels from 120 to $200 \mathrm{pg} / \mathrm{mL}$ were considered borderline and $<120 \mathrm{pg} / \mathrm{mL}$ as B12 deficiency 29 .

\section{Monthly weight gain}

The children were weighted undressed at the time of the first blood sample on an electronic platform scale by Kratos (Kratos Cas, Taboão da Serra, Brazil) with a capacity of $150 \mathrm{~kg}$, accurate to $50 \mathrm{~g}$, with tare function. Weight was measured to obtain mean monthly weight gain, defined as the difference between current weight and birth weight, divided by the decimal age, expressed in months and days.

\section{Statistical analysis}

The coded data were entered in duplicate, performing VALIDATE in Epi Info 6.04d. Statistical analyses used Statistical Package for the Social Sciences version 10.0 (SPSS Inc., Chicago, USA).

Statistical analyses used the following tests: Kolmogorov-Smirnov to assess goodness-of-fit with normal distribution, chi-squared, Student's t, Fisher's exact, paired samples t, and MannWhitney tests, with a significance level of 0.05 or $5 \%$.

Treatment effect was estimated as the absolute risk reduction, relative risk, and relative risk reduction. Absolute risk reduction is the difference in risk between the control group (CR) and treatment group (TR). Relative risk (RR) is the ratio between risk in the treated group and control group. Relative risk reduction expresses the percentage reduction in events in the treatment group (TR) as compared to controls (CR), expressed as [(CR-TR)/CR] x 100\%. Meanwhile, the number needed to treat is the absolute risk reduction number, that is, it demonstrates the number of patients that need to be treated to avoid one case of anemia 30 .

Study protocol no. 098/04 was approved by the Institutional Review Board at the University Hospital of the Federal University in Goiás (UFG) on December 10, 2004.

\section{Results}

\section{Anemia prevalence}

The 196 children from the 25 municipal daycare centers were 6 to 24 months of age when the baseline blood sample was drawn and showed an anemia prevalence of 56.1\% (95\%CI: 48.9-63.1). No children had severe anemia, while 17 (8.7\%; 95\%CI: 5.3-13.7) showed moderate anemia and 93 (47.4\%; 95\%CI: 40.3-54.7) had mild anemia. Mean hemoglobin in the anemic children was $9.9 \pm 0.8 \mathrm{dL}$.

\section{Clinical trial}

Figure 1 shows the flowchart of children that participated in the clinical trial. Children with hemoglobin $\geq 7.0$ and $<8.0 \mathrm{~g} / \mathrm{dL}(\mathrm{n}=4)$, i.e., $2 \%$ of the children, were excluded from the clinical trial, since they began treatment with higher doses of ferrous sulfate, administered twice a day. The attending pediatrician prescribed the medication for all the children participating in the study and those excluded from it. Thus, of 196 children with a baseline complete blood count, 192 participated in the clinical trial, and of these 106 were anemic $(55.2 \%)$ and 86 were non-anemic (44.8\%).

\section{Characteristics of participants in the clinical trial}

Table 1 shows the characteristics of the 192 participants in the four intervention groups and the families' socioeconomic conditions. Among the participants, $97.4 \%$ were from Goiânia and five (2.6\%) from Aparecida de Goiânia.

The study compared the characteristics of anemic and non-anemic children that received ferrous sulfate plus folic acid with those that received ferrous sulfate plus folic acid placebo. No significant differences were observed in gender, decimal age in months, birth weight, per capita income (in times the minimum wage), baseline hemoglobin, baseline ferritin after excluding children with infection (CRP $\geq 0.5$ ), housing conditions, and maternal schooling. The groups were thus homogeneous (Table 1). 
Baseline characteristics of subjects in each group before supplementation with iron plus folic acid versus iron plus folic acid placebo *

\begin{tabular}{|c|c|c|c|c|c|c|}
\hline \multirow[t]{2}{*}{ Variables } & \multicolumn{2}{|c|}{ Anemic } & \multirow[t]{2}{*}{$\mathbf{P}$} & \multicolumn{2}{|c|}{ Non-anemic } & \multirow[t]{2}{*}{$\mathbf{P}$} \\
\hline & Folic acid & Placebo & & Folic acid & Placebo & \\
\hline Male gender (\%) & $57.7(30 / 52)$ & $55.6(30 / 54)$ & $0.85 * \star$ & $56.8(25 / 44)$ & $38.1(16 / 42)$ & 0.09 ** \\
\hline Age (months) & $14.8 \pm 3.7^{\star \star \star}$ & $14.3 \pm 4.5$ & $0.55 \#$ & $16.3 \pm 3.9$ & $16.9 \pm 3.1$ & $0.42 \#$ \\
\hline Birth weight (g) & $3.278 \pm 389$ & $3.387 \pm 444$ & $0.18 \#$ & $3.316 \pm 382$ & $3.420 \pm 367$ & $0.20 \#$ \\
\hline Baseline hemoglobin (g/dL) & $10.0 \pm 0.8$ & $9.9 \pm 0.7$ & $0.30 \#$ & $11.7 \pm 0.6$ & $11.8 \pm 0.6$ & $0.52 \#$ \\
\hline Baseline ferritin $(\mu \mathrm{g} / \mathrm{L}) \# \#$ & $3.8(1.1-6.4) * \star \star$ & $6.3(2.8-11.9)$ & $0.13 \# \# \#$ & $9.5(5.7-14.5)$ & $6.2(4.3-14.8)$ & $0.37 \# \#$ \\
\hline Monthly per capita family & $0.38(0.25-0.68)$ & $0.33(0.22-0.52)$ & $0.26 \# \# \#$ & $0.59 \pm 0.4 * \star \star$ & $0.70 \pm 0.4$ & $0.20 \#$ \\
\hline \multicolumn{7}{|l|}{ income (minimum wage) * } \\
\hline \multicolumn{7}{|l|}{ Maternal schooling (years) } \\
\hline $0-4$ & 13 & 6 & $0.10 * \star$ & 8 & 4 & 0.34 ** \\
\hline $5-8$ & 20 & 30 & & 18 & 15 & \\
\hline$\geq 9$ & 19 & 18 & & 18 & 23 & \\
\hline \multicolumn{7}{|l|}{ Home * } \\
\hline Own or loaned & 19 & 27 & $0.19 * \star$ & 19 & 22 & $0.39 * \star$ \\
\hline Rented or financed home & 32 & 27 & & 25 & 20 & \\
\hline \multicolumn{7}{|l|}{ Water } \\
\hline Treated & 46 & 49 & $0.95 * \star$ & 42 & 37 & $0.26 \S$ \\
\hline Cistern & 6 & 5 & & 2 & 5 & \\
\hline \multicolumn{7}{|l|}{ Sewage disposal } \\
\hline Sewerage & 34 & 31 & $0.40 * \star$ & 24 & 26 & $0.49 * \star$ \\
\hline Cesspool or open ditch & 18 & 23 & & 20 & 16 & \\
\hline
\end{tabular}

* Excluding children with hemoglobin $\geq 7$ and $<8 \mathrm{~g} / \mathrm{dL}$; one child lived in a squatting settlement. All the children received a therapeutic or prophylactic dose of ferrous sulfate plus folic acid or placebo;

** $\chi^{2}$ test;

*** Mean \pm standard deviation or median (P25 - P75);

\# Student's $t$ test for independent samples:

\#\# Excluding children with infection (PCR $\geq 0.5)$ from the ferritin analysis;

\#\#\# Mann-Whitney test;

$\S$ Fisher's exact test.

There was a statistically significant difference in relation to hemoglobin level and decimal age (months) at the time of the first blood count, when comparing anemic and non-anemic children (data not shown).

When evaluating whether the children that concluded treatment differed from those that dropped out, no significant difference was observed in serum hemoglobin, folic acid, vitamin $\mathrm{B} 12$, or ferritin in relation to gender, per capita family income, maternal schooling, mean monthly weight gain, and proportion of anemic subjects. Only decimal age was lower among treatment dropouts (Table 2).

\section{Effects of the intervention}

Table 3 shows the effects of treatment for anemia in the treatment and control groups with and without folic acid.
Among the anemic children that completed treatment with ferrous sulfate plus folic acid, final anemia prevalence was $14 \%$. However, among the anemic children that received ferrous sulfate plus folic acid placebo, final anemia prevalence was $34.9 \%$. Folic acid was a protective factor for the reduction of anemia prevalence $(p=0.02)$, as shown by comparison to anemic children that received folic acid placebo (Table 3).

The incidence of anemia among children that received prophylactic iron plus folic acid was lower than those receiving iron plus folic acid placebo, but the difference was not statistically significant (Table 3).

Final prevalence of anemia in anemic and non-anemic children treated with ferrous sulfate plus folic acid was $10.1 \%$ (8/79), as compared to $23.2 \%(19 / 82)$ among those that received ferrous sulfate plus placebo (Table 3 ). 
Comparison of subjects that concluded treatment and dropouts *

\begin{tabular}{|c|c|c|c|c|c|}
\hline \multirow[t]{2}{*}{ Variables } & \multicolumn{2}{|c|}{ Concluded } & \multicolumn{2}{|c|}{ Dropped out of } & \multirow[t]{2}{*}{$\mathbf{p}$} \\
\hline & $\mathbf{n}$ & Treatment & $\mathrm{n}$ & Treatment & \\
\hline Baseline hemoglobin $(\mathrm{g} / \mathrm{dL})$ & 161 & $10.8 \pm 1.1$ & 31 & $10.7 \pm 1.1$ & $0.81 * \star$ \\
\hline Baseline folic acid (ng/mL) & 157 & $13.0 \pm 5.4$ & 31 & $12.7 \pm 5.0$ & $0.75^{\star \star}$ \\
\hline Birth weight (g) & 160 & $3.369 \pm 387$ & 30 & $3.398 \pm 471$ & $<0.46 * \star$ \\
\hline 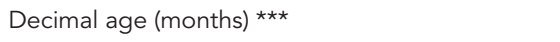 & 161 & $15.9 \pm 4.0$ & 31 & $13.4 \pm 3.5$ & 0.002 ** \\
\hline Male gender (\%) & 161 & $54(87 / 161)$ & 31 & $45.2(14 / 31)$ & $0.36 \#$ \\
\hline Per capita income (no. times the minimum wage) & 161 & $0.41(0.25-0.70)$ & 31 & $0.50(0.38-0.69)$ & $0.12 \# \#$ \\
\hline Maternal schooling (years) & 161 & & 31 & & $0.45 \#$ \\
\hline $0-4$ & & 24 & & 7 & \\
\hline $5-8$ & & 69 & & 14 & \\
\hline$\geq 9$ & & 68 & & 10 & \\
\hline Mean monthly weight gain (g) & 159 & $434(381-530)$ & 29 & $456(426-563)$ & $0.11 \# \#$ \\
\hline Baseline ferritin $(\mu \mathrm{g} / \mathrm{L})$ & 148 & $8.1(4.3-18.5)$ & 31 & $10.2(3.3-18.7)$ & $0.85 \# \#$ \\
\hline Baseline vitamin B12 (pg/mL) & 157 & 565 (427-719) & 31 & $502(371-732)$ & $0.29 \# \#$ \\
\hline Anemic (\%) & 161 & $53.4(n=86)$ & 31 & $64.5(n=20)$ & $0.26 \#$ \\
\hline
\end{tabular}

* Excluding children with hemoglobin $\geq 7$ and $<8 \mathrm{~g} / \mathrm{dL}$. Mean \pm standard deviation or median (P25 - P75);

** Student's t test;

*** Decimal age, expressed as age in months and days;

\# $\chi^{2}$ test;

\#\# Mann-Whitney test.

The absolute risk reduction was 0.21 . Thus, the group treated with active folic acid showed $21 \%$ less anemia than the group that received folic acid placebo.

The group treated with folic acid showed a relative risk of anemia of 0.40 (95\%CI: $0.17-0.93$ ) compared to the control group, showing that the intervention was highly beneficial. The risk of remaining anemic in the placebo group was 2.5 times that of the group that received folic acid. The odds ratio was 0.3 , i.e., similar to the value obtained for relative risk.

Relative risk reduction was $60 \%$, meaning that treatment with ferrous sulfate plus folic acid allowed a $60 \%$ reduction in anemia compared to the group treated with ferrous sulfate plus folic acid placebo.

The number needed to treat (NNT) with ferrous sulfate and folic acid to avoid anemia was five patients treated to avoid one case of anemia.

Pre and post-treatment hemoglobin levels showed a significant increase in anemic individuals, both for those that received folic acid and those receiving placebo. Among non-anemic individuals, the increase only occurred in the group that received folic acid $(p=0.003)$. However, there was no statistically significant difference when comparing hemoglobin levels between the active folic acid and placebo groups (Table 4).
Table 3

Prevalence of anemia in children with baseline anemia and incidence in non-anemic children after therapeutic or prophylactic dose.

\begin{tabular}{|c|c|c|c|c|}
\hline \multirow[t]{2}{*}{ Group } & \multicolumn{2}{|c|}{ Final anemia } & \multicolumn{2}{|c|}{ Total } \\
\hline & Yes & No & $\mathbf{n}$ & $\%$ \\
\hline \multicolumn{5}{|l|}{ Baseline anemia *.** } \\
\hline Treated with com iron + folic acid ${ }^{\star \star \star}$ & 6 & 37 & 43 & 14.0 \\
\hline Treated with iron + folic acid placebo \# & 15 & 28 & 43 & 34.9 \\
\hline \multicolumn{5}{|l|}{ Non-anemic \#\# } \\
\hline Prophylaxis with iron + folic acid & 2 & 34 & 36 & 5.6 \\
\hline Prophylaxis with iron + folic acid placebo & 4 & 35 & 39 & 10.3 \\
\hline
\end{tabular}

* $\chi^{2}$ calc $=5.10 ; p=0.02 ;$

** Absolute risk reduction: $0.35-0.14=0.21$; Relative risk reduction: $[(0.21 / 0.35)] \times 100.0 \%$

$=60.0 \%$; Number needed to treat: $1 / 0.21=5$;

$\star \star \star$ Risk in treated group: $6 / 43=0.14$

\# Risk in control group: $15 / 43=0.35$;

\#\# Fisher's exact test, $p=0.38$.

\section{Number of doses received}

When evaluating the number of doses or days of medication, we observed that the $25^{\text {th }}$ percentile, median, and $75^{\text {th }}$ percentile in the number of doses received were 66,67 , and 70 , respectively in 
Mean hemoglobin concentrations $(\mathrm{g} / \mathrm{dL})$ in anemic and non-anemic children before and after treatment with ferrous sulfate plus folic acid or folic acid placebo *

\begin{tabular}{|c|c|c|c|c|c|}
\hline Groups/Variables & $\mathbf{n}$ & $\begin{array}{c}\text { Baseline Hb } \\
\text { Mean } \pm \text { SD }\end{array}$ & $\begin{array}{c}\text { Final } \mathrm{Hb} \\
\text { Mean } \pm \mathrm{SD}\end{array}$ & $\mathrm{p}$ & $\begin{array}{l}\text { Hb increase } \\
\text { Mean } \pm \text { SD }\end{array}$ \\
\hline \multicolumn{6}{|l|}{ Treatment of anemic subjects } \\
\hline $\mathrm{Fe}+$ folic acid & 43 & $9.96 \pm 0.77$ & $11.5 \pm 0.8$ & $<0.001 * \star$ & $1.56 \pm 0.91$ \\
\hline $\mathrm{Fe}+$ folic acid placebo & 43 & $9.93 \pm 0.7$ & $11.3 \pm 1.0$ & $<0.001 \star \star$ & $1.32 \pm 1.2$ \\
\hline Folic acid X placebo & & $\mathrm{p}=0.87 \star \star \star$ & $\mathrm{p}=0.19 \star \star \star$ & & \\
\hline \multicolumn{6}{|l|}{ Prophylaxis in non-anemic } \\
\hline $\mathrm{Fe}+$ folic acid & 36 & $11.7 \pm 0.58$ & $12.1 \pm 0.8$ & $0.003 * \star$ & $0.41 \pm 0.78$ \\
\hline $\mathrm{Fe}+$ folic acid placebo & 39 & $11.8 \pm 0.58$ & $12.0 \pm 0.9$ & $0.07 * \star$ & $0.25 \pm 0.85$ \\
\hline Folic acid X placebo & & $p=0.68 * \star \star$ & $p=0.59 * \star \star$ & & \\
\hline
\end{tabular}

SD: standard deviation

* Excluding children with hemoglobin $\geq 7$ and $<8 \mathrm{~g} / \mathrm{dL}_{\text {; }}$

** Paired samples $t$ test;

*** Student's t test applied to the children that participated in both blood samples.

both the anemic $(\mathrm{n}=86)$ and non-anemic group $(\mathrm{n}=75)$. The Mann-Whitney test showed that the two groups did not differ as to the number of doses received $(\mathrm{p}=0.71)$.

Comparing the anemic and non-anemic groups, there was also no difference in the number of doses received in the folic acid group as compared to the placebo group.

The number of doses or scheduled days of treatment was 67 days, so no children that participated in the second post-intervention blood sample showed low adherence (i.e., no children received fewer than $75 \%$ of the scheduled doses).

\section{Serum folic acid in children in the clinical trial}

Among the children with baseline anemia, serum folic acid levels did not differ between the groups. However, after the intervention the active folic acid group showed significantly higher folic acid levels than the placebo group (Table 5). Folic acid level increased significantly after supplementation with ferrous sulfate plus folic acid, but not with ferrous sulfate and placebo (Table 5).

Among children without baseline anemia, serum folic acid did not differ from the first to the second blood sample. Although there was an upward trend in the folic acid group, it was not statistically significant ( $p=0.055$, Table 5).

\section{Discussion}

The current study was part of a larger research project on the assessment of nutritional ane- mia in early childhood, conducted at municipal daycare centers in Goiânia. The principal focus was supplementation with two micronutrients, iron and folic acid, to prevent and treat anemia.

The municipal daycare centers contribute to the child's development and allow the mother to participate in the labor market, which in turn leads to greater availability of food in the home 31 . However, if the center is located far from the mother's workplace, it does not allow exclusive breastfeeding up to six months of age, considering that the official maternity leave in Brazil is only four months.

According to one study, children enrolled in a daycare center showed improved nutrient intake 32 , while another study showed inadequate food consumption among children attending a daycare center 31 .

The prevalence of anemia in this study (56.1\%) among children 6 to 24 months of age in the 25 municipal daycare centers in Goiânia is similar that in other studies performed in the same city. Hadler et al. 33 observed a $60.9 \%$ anemia prevalence in 110 infants 6 to 12 months of age, while in a study in daycare centers with children 1 to 48 months of age the prevalence was $51 \% 34$. Other Brazilian studies have shown even higher prevalence than in the current study. In municipal daycare centers in the city of São Paulo, prevalence of anemia was $65.3 \%$ among children 6 to 12 months of age and $69 \%$ from 12 to 24 months 14 . In Cuiabá, the prevalence was $82 \%$ in children 6 to 24 months of age 35 . Analyzed jointly, these data confirm that 
Serum folic acid $(\mathrm{ng} / \mathrm{mL})$ in anemic and non-anemic children that received ferrous sulfate plus folic acid or placebo in the pre and post-intervention periods *.

\begin{tabular}{|c|c|c|c|c|c|}
\hline \multirow{2}{*}{$\begin{array}{l}\text { Groups and time of } \\
\text { blood sample }\end{array}$} & \multicolumn{2}{|c|}{ Folic acid group } & \multicolumn{2}{|c|}{ Placebo group } & \multirow[t]{2}{*}{$p$} \\
\hline & $\mathrm{n}$ & $\begin{array}{l}\text { Serum folic acid } \\
\text { Mean } \pm \text { SD }\end{array}$ & $\mathrm{n}$ & $\begin{array}{l}\text { Serum folic acid } \\
\text { Mean } \pm \text { SD }\end{array}$ & \\
\hline \multicolumn{6}{|l|}{ Anemic } \\
\hline Pre & 50 & $11.0 \pm 4.7$ & 52 & $12.8 \pm 4.8$ & $0.065 * \star$ \\
\hline Post & 43 & $14.6 \pm 4.8$ & 43 & $12.4 \pm 4.3$ & 0.027 ** \\
\hline \multicolumn{6}{|l|}{ Folic acid group } \\
\hline Pre & 41 & $10.7 \pm 4.6$ & & & 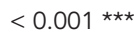 \\
\hline Post & 41 & $14.8 \pm 4.8$ & & & \\
\hline \multicolumn{6}{|l|}{ Placebo group } \\
\hline Pre & & & 41 & $13.0 \pm 5.1$ & $0.507 * \star \star$ \\
\hline Post & & & 41 & $12.4 \pm 4.2$ & \\
\hline \multicolumn{6}{|l|}{ Non-anemic } \\
\hline Pre & 44 & $13.5 \pm 5.7$ & 42 & $15.0 \pm 5.4$ & 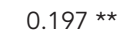 \\
\hline Post & 36 & $15.6 \pm 5.2$ & 39 & $15.1 \pm 5.1$ & $0.688 * \star$ \\
\hline \multicolumn{6}{|l|}{ Folic acid group } \\
\hline Pre & 36 & $13.3 \pm 5.5$ & & & $0.055 * \star \star$ \\
\hline Post & 36 & $15.6 \pm 5.2$ & & & \\
\hline \multicolumn{6}{|l|}{ Placebo group } \\
\hline Pre & & & 39 & $15.3 \pm 5.5$ & $0.861 * * *$ \\
\hline Post & & & 39 & $15.1 \pm 5.1$ & \\
\hline
\end{tabular}

SD: standard deviation.

* Excluding children with hemoglobin $\geq 7$ and $<8 \mathrm{~g} / \mathrm{dL}$ and those without hemoglobin values from the second blood sample;

** Student's t test for independent samples;

$\star \star \star$ Paired samples t test.

children less than 24 months of age constitute one of the main risk groups for anemia 10,36,37.

In the municipal daycare centers in this study, among anemic children less than 18 months of age, $17.9 \%(15 / 84)$ showed $\mathrm{Hb}<9.0 \mathrm{~g} / \mathrm{dL}$, while in the city of São Paulo similar hemoglobin levels were found in one-third of anemic children in this age bracket 15 .

Food fortification, supplementation, and nutritional education programs have been recommended to fight anemia 4 . In Brazil, Ruling $R D C$ 344 of December 13, 200238 requires fortification of wheat flour and corn meal and corn flakes with $4.2 \mathrm{mg}$ of bioavailable iron and $150 \mu \mathrm{g}$ of folic acid per $100 \mathrm{~g}$ of food product, as one of the measures to fight anemia and reduce the risk of neural tube defects and myelomeningocele.

Supplementation with ferrous sulfate and folic acid to treat anemia proved more effective than ferrous sulfate with placebo and was a protective factor against anemia, since the reduction in anemia prevalence was significantly greater.
Although the children did not present folic acid deficiency at baseline, administration of this micronutrient allowed a significant increase in serum folic acid and a greater and quicker reduction in anemia prevalence. This proves that folic acid can be combined with ferrous sulfate supplementation to treat anemia.

The Brazilian Ministry of Health created the National Iron Supplementation Program to prevent anemia in children from 6 to 18 months of age, using $25 \mathrm{mg}$ of elemental iron/week 40 . A scientific report by the Department of Nutrition of the Brazilian Pediatric Society in February 200740 contends that the above supplementation has still not been properly proven, especially in Brazil, and recommends, for prophylaxis of anemia, that when infants (born at term with adequate-for-gestational age birth weight) begin receiving complementary food (besides breastfeeding), they should receive $1 \mathrm{mg}$ of elemental iron $/ \mathrm{kg}$ body weight/day unless they consume a minimum of $500 \mathrm{~mL} /$ day of iron- 
enriched baby formula 40 . The existence of two different recommendations hinders the implementation of a supplementation program.

Silva 16 compared different doses of ferrous sulfate for prevention of anemia in children 6 to 12 months of age and showed that the daily dose of $1 \mathrm{mg} / \mathrm{kg} /$ day recommended by the Brazilian Pediatric Society 40 , which is the dose used in the current study, had better results than $2 \mathrm{mg} /$ $\mathrm{kg} /$ day, or the weekly dose recommended by the Ministry of Health.

Definition of the recommended dose is also based on the child's iron nutritional status 4 . Anemic children receive a therapeutic dose, while non-anemic children receive prophylactic doses, like those administered in this and other studies in Brazil 4,16,35. However, some studies have used the same amount of iron for both prevention and treatment of anemia 15,41,42.

The results of the current intervention demonstrate that the administration of $4.2 \mathrm{mg}$ of ferrous sulfate $/ \mathrm{kg} /$ day significantly increased the hemoglobin level in anemic children, both in groups receiving folic acid and those receiving folic acid placebo. The reduction in the prevalence of anemia was higher in those that also received folic acid, and although the increase in hemoglobin $(1.56 \pm 0.91 \mathrm{~g} / \mathrm{dL})$ was higher than in those that received placebo $(1.32 \pm 1.2 \mathrm{~g} / \mathrm{dL})$, the difference between the two groups was not statistically significant $(p=0.19)$. There are controversies as to the effect of iron and micronutrient supplementation on child morbidity 43,44 , including the non-recommendation of prophylaxis in areas with a high prevalence of malaria 44 .
Even some non-anemic children that received a prophylactic dose of ferrous sulfate presented anemia, in both the active folic acid and placebo groups. Other studies have also shown some anemia incidence in children receiving a prophylactic dose, using different types of iron in the medication 16,45 .

In the non-anemic children, the final anemia incidence did not differ between the groups, although there was an increase in hemoglobin among those receiving ferrous sulfate plus folic acid ( $p=0.003$ ), but not in those receiving placebo. Still, final hemoglobin did not differ between the two groups.

\section{Conclusions and recommendations}

Anemia prevalence was high in under-two children attending municipal daycare centers in Goiânia, even with the use of iron and folic acid supplemented flours.

A supplementation program with ferrous sulfate and folic acid, as developed in this study, proved effective in the reduction of anemia prevalence in children and improved the hemoglobin levels in non-anemic children. Such a program is easy to implement and does not require that the mother administer the medication at home. The children require nutritional follow-up and monitoring of anemia, and this type of program can be developed at municipal daycare centers or preschools. 


\section{Resumo}

Avaliar a prevalência de anemia e a resposta terapêutica e profilática do sulfato ferroso e ácido fólico. Realizou-se um ensaio clínico controlado randomizado, duplo-cego, com 196 crianças de 6 a 24 meses, dos Centros Municipais de Educação Infantil de Goiânia, Goiás, Brasil. As crianças foram alocadas em dois grupos de tratamento que receberam dose diária (5x/semana) com 4,2mg/kg/dia de sulfato ferroso + ácido fólico (50 $\mathrm{\mu g}$ ) ou $4,2 \mathrm{mg} / \mathrm{kg} /$ dia de sulfato ferroso + placebo de ácido fólico. Um dos grupos de prevenção recebeu 1,4 $\mathrm{mg} / \mathrm{kg} /$ dia de sulfato ferroso + ácido fólico (50 $\mu \mathrm{g} / \mathrm{dia})$ e o outro $1,4 \mathrm{mg} / \mathrm{kg} /$ dia de sulfato ferroso + placebo de ácido fólico. A suplementação durou cerca de três meses. A prevalência de anemia inicial foi de 56,1\% (IC95\%: 48,9-63,1). Após o tratamento, a prevalência de anemia no grupo ácido fólico (14\%) foi menor que no grupo placebo $(34,9 \% ; p=0,02)$. Após profilaxia dos não anêmicos, a incidência de anemia não diferiu entre os grupos, porém, houve incremento da hemoglobina no grupo ácido fólico $(p=0,003)$. O ferro associado com ácido fólico foi eficaz no tratamento da anemia e na melhoria da hemoglobina nos não anêmicos.

Epidemiologia Nutricional; Anemia; Sulfato Ferroso; Ácido Fólico; Creches

\section{Contributors}

All the authors participated in the study design. M. C. C. M. Hadler coordinated the research, supervised the fieldwork, and participated in the data collection, processing, and analysis and drafting of the article. D. M. Sigulem and M. F. C. Alves also contributed to the data analysis, consultancy, and drafting of the article. V. M. Torres participated in the data collection and analysis, prescribed the medication, and conducted the clinical evaluation and follow-up of the children.

\section{Acknowledgments}

The authors wish to thank the children and their parents, the teachers and staff at the municipal daycare centers, the students and interns from the Course on Nutrition at the Federal University in Goiás (UFG), the young scientist scholarship students under the Institutional Program for Scientific Initiation Scholarships (PIBIC) of the Brazilian National Research Council (CNPq/UFG), Suziane Severino and Daianni Chaves, nutritionist Fernanda Beraldo, the CNPq technical support scholarship student Hélio Teixeira, and the Goiânia Municipal Department of Education, as well as the Department of Science and Technology/ Secretariat of Science, Technology, and Strategic Inputs of the Ministry of Health, and the Health Sector Fund, through the CNPq (Project: CT-SAUUDE/MCT/MS/CNPq no. 30/2004, Grant 506193/2004-7), and the Goiânia Municipal Health Department and the University Hospital of the Federal University in Goiás

\section{References}

1. Dallman PR, Yip R, Johnson C. Prevalence and causes of anemia in the United States, 1976 to 1980. Am J Clin Nutr 1984; 39:437-45

2. Organización Mundial de la Salud. Lucha contra la anemia nutricional, especialmente contra la carencia de hierro. Geneva: Organización Mundial de la Salud; 1975. (Serie de Informes Técnicos, 580).

3. Institute of Medicine. Food and nutrition board. Folate. In: Institute of Medicine, editor. Dietary reference intakes for thiamin, riboflavin, niacin, vitamin B6, folate, vitamin B12, pantothenic acid, biotin, and choline. Washington DC: National Academies Press; 1998. p. 196-305.

4. World Health Organization/United Nations Children's Fund/United Nations University. Iron deficiency anaemia. Assessment, prevention and control. A guide for programme managers. Geneva: World Health Organization; 2001.
5. DeMayer E, Adiels-Tegman M. The prevalence of anemia in the world. World Health Stat Q 1985; 38:302-16.

6. Walter T. Effect of iron-deficiency anaemia on cognitive skills in infancy and childhood. Baillieres Best Pract Res Clin Haematol 1994; 7:815-27.

7. Lozoff B, Wolf AW, Jimenez E. Iron deficiency anemia and infant development: effects of extended oral iron therapy. J Pediatr 1996; 129:382-9.

8. Wieringa FT, Dijkhuizen MA, van der vemJongekrijg, West CE, Muhihal, van der Meer JWM. Micronutrient deficiency and supplementation in Indonesian infants. Effects on immune function. Adv Exp Med Biol 2003; 531:369-77.

9. Hadler MCCM. Anemia ferropriva do lactente: conhecimentos e atitudes maternas, práticas alimentares e fatores de risco [Masters Thesis]. São Paulo: Universidade Federal de São Paulo; 1998. 
10. Assis AMO, Barreto ML, Gomes GSS, Prado MS, Santos NS, Santos LM, et al. Childhood anemia prevalence and associated factors in Salvador, Bahia, Brazil. Cad Saúde Pública 2004; 20:1633-41.

11. Secretaria de Política de Saúde, Ministério da Saúde/Organização Pan-Americana da Saúde. Guia alimentar para crianças menores de 2 anos. Brasília: Ministério da Saúde; 2002.

12. World Health Organization. Complementary feeding of young children in developing countries: a review of current scientific knowledge. Geneva: World Health Organization; 1998.

13. Beaton GH, McCabe GP. Efficacy of intermittent iron supplementation in the control of iron deficiency anemia in developing countries. An analysis of experience: final report to the micronutrient initiative. Ottawa: The Micronutrient Initiative; 1998.

14. Ribeiro LC. Anemia ferropriva na primeira infância: controle e prevenção com doses intermitentes de ferro quelato glicinato [Masters Thesis]. São Paulo: Universidade Federal de São Paulo; 2001.

15. Monteiro CA, Szarfarc SC, Brunken GS, Gross R, Conde WL. A prescrição semanal de sulfato ferroso pode ser altamente efetiva para reduzir níveis endêmicos de anemia na infância. Rev Bras Epidemiol 2002; 5:71-83

16. Silva DG. Prevalência da anemia e da deficiência de ferro no segundo semestre de vida com diferentes suplementações de ferro [Doctoral Dissertation]. São Paulo: Universidade Federal de São Paulo; 2007.

17. Sankaranarayanan S, Untoro J, Erhardt J, Gross R, Rosales FJ. Daily iron alone but not in combination with micronutrients increases plasma ferritin concentrations in Indonesian infants with inflammation. J Nutr 2004; 134:1916-22.

18. Allen LH, Rosado JL, Casterline JE, López P, Muñoz E, Garcia OP, et al. Lack of hemoglobin response to iron supplementation in anemic Mexican preschoolers with multiple micronutrient deficiencies. Am J Clin Nutr 2000; 71:1485-94.

19. Dijkhuizen MA, Wieringa FT, West CE, Muhilal. Micronutrient deficiency and supplementation in Indonesian infants. Interactions among micronutrients. Adv Exp Med Biol 2003; 531:359-68

20. Stoltzfus RJ, Dreyfuss ML. Guidelines for the use of iron supplements to prevent and treat iron deficiency anemia. Washington DC: ILSI Press; 1998.

21. Trowbridge F, Martorell R. Summary and recommendations. J Nutr 2002; 132 Suppl 4:875-9.

22. Tee E-S, Kandiah M, Awin N, Chong S-M, Satgunasingam N, Kamarudin L, et al. School-administered weekly iron-folate supplements improve hemoglobin and ferritin concentrations in Malaysian adolescent girls. Am J Clin Nutr 1999; 69:1249-56.

23. Whitehead RG. Ethical aspects of nutritional research on infants in developing countries. In: Perman JA, Rey J, editors. Clinical trials in infant nutrition. Philadelphia: Veyey/Lippincott-Raven; 1998. p. 33-45.

24. Sociedade Brasileira de Pediatria. Preconização da profilaxia de ferro em lactentes. Atualidades SBP 1995; 4:12.

25. American Academy of Pediatrics. Iron supplementation for infants. Pediatrics 1976; 58:765-8.
26. Centers for Disease Control and Prevention. Recommendations to prevent and control iron deficiency in the United States. Morb Mortal Wkly Rep 1998; 47(RR-3):1-36.

27. DeMayer EM. Preventing and controlling iron de ficiency anaemia through primary health care. Geneva: World Health Organization; 1989.

28. Bailey LB, Gregory JF. Folate metabolism and requirements. J Nutr 1999; 129:779-82.

29. National Committee for Clinical Laboratory Standards. How to define, determine and utilize reference intervals in the clinical laboratory; approved guidelines. Wayne: National Committee for Clinical Laboratory Standards; 1995. (NCCLS document C28-A).

30. Escoteguy CC. Estudos de intervenção. In: Medronho RA, Carvalho DM, Bloch KV, Luiz RR, Werneck GL, organizadores. Epidemiologia. São Paulo: Editora Atheneu; 2003. p. 151-60.

31. Spinelli MGN, Goulart RMM, Santos ALP, Gumiero LDC, Farhud CC, Freitas EB, et al. Consumo alimentar de crianças de 6 a 18 meses em creches. Rev Nutr 2003, 16:409-14.

32. Barbosa RMS, Soares E, Lanzilotti HS. Avaliação da ingestão de nutrientes de crianças de uma creche filantrópica: aplicação do consumo dietético de referência. Rev Bras Saúde Matern Infant 2000; 7:159-66

33. Hadler MCCM, Juliano Y, Sigulem DM. Anemia do lactente: etiologia e prevalência. J Pediatr (Rio J) 2002; 78:321-6.

34. Corrêa NBO, Pinto SL, Rodrigues RB, Ximenes JD, Castor EF, Fisberg M, et al. Avaliação do nível de hemoglobina em crianças de creche do município de Goiânia. In: Programa oficial do 6o Congresso Goiano de Pediatria. Goiânia: Sociedade Goiana de Pediatria; 1999. p. 18-9.

35. Brunken GS, Guimarães LV, Fisberg MF. Anemia em crianças menores de 3 anos que freqüentam creches públicas em período integral. J Pediatr (Rio J) 2002; 78:50-6.

36. Vannucchi H, Freitas MLS, Szarfarc SC. Prevalência de anemias nutricionais no Brasil. Cadernos de Nutrição 1992;4:7-26.

37. Hadler MCCM, Colugnati FAB, Sigulem DM. Risks of anemia in infants according to dietary iron density and weight gain rate. Prev Med 2004; 39:713-21.

38. Agência Nacional de Vigilância Sanitária. Resolução RDC n³44, de 13 de dezembro de 2002. http:// www.anvisa.gov.br/legis/resol/2002/ 344_02rdc.htm (acessado em 28/Nov/2007).

39. Ministério da Saúde. Manual operacional do Programa Nacional de Suplementação de Ferro. Brasília: Ministério da Saúde; 2005.

40. Sociedade Brasileira de Pediatria. Anemia carencial ferropriva. http://www.sbp.com.br/img/ documentos/doc_anemia_carencial_ferropriva. pdf. (acessado em 05/Set/2007).

41. Liu X-N, Kang J, Zhao L, Viteri FE. Intermittent iron supplementation in Chinese preschool children is efficient and safe. Food Nutr Bull 1995; 16:139-46

42. Geltman PL, Meyers AF, Mehta SD, Brugnara C, Villon I, Wu YA, et al. Daily multivitamins with iron to prevent anemia in high-risk infants: a randomized clinical trial. Pediatrics 2004; 114:86-93. 
43. Tielsch JM, Kathry SK, Stoltzfus R, Katz J, LeClerq $\mathrm{S}$, Adhikari R, et al. Effect of routine prophylactic supplementation with iron and folic acid on preschool child mortality in southern Nepal: community-based, cluster-randomised, placebo-controlled trial. Lancet 2006: 367:144-52.

44. Sazawal S, Black RE, Ramsan M, Chwaya HM, Stoltzfus RJ, Dutta A, et al. Effects of routine prophylactic supplementation with iron and folic acid on admission to hospital and mortality in preschool children in a high malaria transmission setting: community-based, randomized, placebocontrolled trial. Lancet 2006; 367: 133-143.
45. Ribeiro LC. Anemia por deficiência de ferro: suplementação terapêutica e profilática em creches [Doctoral Dissertation]. São Paulo: Universidade Federal de São Paulo; 2005.

Submitted on $14 /$ Sep/2007

Final version resubmitted on 05/Mar/2008

Approved on 24/Mar/2008 